\title{
Linear Alkylbenzene Sulfonate tolerance in bacteria isolated from sediment of tropical water bodies polluted with detergents
}

\author{
Kehinde I.T. Eniola \& Albert B. Olayemi \\ 1. Environmental and Public Health Research (EPHR) Laboratory, \\ 2. Department of Microbiology, University of Ilorin, P.M.B. 1515, Ilorin, Kwara State, Nigeria; \\ kennyeniola@yahoo.com,ephr_lab@yahoo.co.uk
}

\author{
Received 24-VIII-2007. Corrected 30-VI-2008. Accepted 31-VII-2008.
}

\begin{abstract}
The discharge of untreated detergent-bearing waste introduces linear alkylbenzene sulfonates (LAS) to the aquatic environment. The surfactant persists in some streams and rivers in Nigeria, some is adsorbed to suspended materials and end in the sediment of the receiving water bodies. In this study, bacteria isolated from sediments of some tropical detergent-effluent-polluted streams were tested for tolerance to LAS using the media dilution technique. LAS-tolerance was indicated by growth of the bacteria in the presence of the surfactant. The $\mathrm{pH}$, concentrations of surfactant, population of heterotrophic bacteria and population of LAS-tolerant bacteria in the sediments were determined. A direct relationship ( $\mathrm{r}=0.9124)$ was found between the alkaline conditions $(\mathrm{pH}=8.2-12.0)$ and high surfactant concentrations $(45-132 \mathrm{mg} / \mathrm{g})$ in the sediment. The sediments harboured a high population and a wide variety of bacteria; the populations of viable heterotrophic bacteria (VHB: $2.9 \times 10^{5}$ to $1.2 \times 10^{7} \mathrm{cfu} / \mathrm{g}$ ) and LAS tolerant bacteria (LTB: $1.5 \times 10^{4}$ to $1.2 \times 10^{6} \mathrm{cfu} / \mathrm{g}$ ) had a direct relationship $(\mathrm{r}=0.9500)$. An inverse relationship resulted between each of them and the concentration of surfactant in the sediment, $\mathrm{r}_{\mathrm{VHB} / \mathrm{LAS}}=-0.9303$ and $\mathrm{r}_{\mathrm{LTB} / \mathrm{LAS}}=-0.9143$, respectively. Twelve bacteria species were isolated from the sediment: Alcaligenes odorans, Bacillus subtilis, Burkholderia cepacia, Citrobacter freundii, Citrobacter diversus, Escherichia coli, Micrococcus luteus, Micrococcus albus, Pseudomonas putida, Pseudomonas stutzeri, Staphylococcus aureus and Streptococcus faecalis. Most of them were adapted to the surfactant with their maximum acceptable concentrations ranging between 0.03 and $>1.0 \%(\mathrm{w} / \mathrm{v})$. The sediments could serve as source of adapted organisms which can be used in bio-treatment of LAS-bearing waste. Rev. Biol. Trop. 56 (4): 1595 1601. Epub 2008 December 12.
\end{abstract}

Key word: LAS, surfactant, tolerance, detergent, effluent.

Linear alkylbenzene sulfonate (LAS) is an amphiphilic surfactant with a high solid-adsortion coefficient and readily adsorbs onto colloidal surfaces, suspended particles and solid substrates in water (Painter and Zabel 1989). It is widely used in the detergent Industry and gets into the environment via a variety of sources (Larson et al. 1995, CLER 1996, Takada et al. 1997). LAS is removed from the environment by a variety of processes; however, biodegradation and sorption to suspended materials are reported to be the main mechanisms (WHO 1996, Takada et al. 1997, Schulze and Tiehm 2004). It has been estimated that between 20 to $50 \%$ of LAS is removed from water by adsorption unto solids. The adsorption of the surfactant is influenced by the physicochemical properties of the sediment, by those of the surfactant and by those of the solution with which it is in contact (Dentel et al. 1993).

Cavalli et al. (2000) reported that the suspended solids in the water column are the major constituents that form the sediment along the water course. LAS that adsorbed to suspended particles would likely end up in the sediment if the supporting particles are large or have a higher density than water. However, adsorbed LAS may occur in suspension if 
the particles are sufficiently small. LAS can also be associated with the cell membrane in living organisms including bacteria (Folker and Landner 2000). The settling of suspended solids to which LAS has adsorbed and the slow pace of degradation/ persistence of LAS in sediment (Dentel et al. 1993, Jacques Whitford Limited 2006) would result in persistence of LAS in sediments.

The sediment of water bodies have been shown to contain a higher concentration of LAS than the overlaying water (de Ferrer et al. 1996, Olayemi et al. 2003). Bacteria resident in the sediments will therefore be exposed to higher concentrations of the surfactant for a longer time than bacteria that are in the overlying water column. This kind of exposure could be crucial as indicated by Takada et al. (1997) in explaining the accelerated degradation of LAS when sediments from sites previously exposed to LAS were added to their preparation. Brock et al. (1994) had pointed out that surfaces were important because they allow attachment of organisms, accumulate nutrients and may even serve as nutrient themselves.

A study by Eniola and Olayemi (2003) showed that there was a difference in the composition of bacterial flora of water and sediment of some detergent polluted water bodies in Ilorin, Nigeria. This study examines the LAS-tolerance of bacteria isolated from sediments from some detergent-effluent-polluted streams in Ilorin Nigerian. The tolerances will be assessed in terms of ability or failure to grow in the presence of $0.1 \%(\mathrm{w} / \mathrm{v})$ of the surfactant, using the media dilution technique.

\section{MATERIALS AND METHODS}

\section{Study Area/ Sampling points}

The study was undertaken using the major river Asa River and two of its tributary streams: Okun and Osere streams in Ilorin, North Central Nigeria ( $8^{\circ} 28^{\prime} \mathrm{N}, 4^{\circ} 38^{\prime} \mathrm{E}$ to $\left.8^{\circ} 31^{\prime} \mathrm{N}, 4^{\circ} 40^{\prime} \mathrm{E}\right)$. The river, through the tributaries, regularly receives untreated detergent-bearing-effluent from a soap and detergent industry as well as residential buildings. Samples of sediment were collected from two points along the course of each of the water body Samples were collected by digging about $1 \mathrm{~cm}$ into the sediment using a sterile spatula. The samples were collected into sterile sampling bottles. Samples were collected in triplicate and taken to the laboratory for analysis in an improvised ice chest.

\section{Physicochemical Analysis of Samples}

A suspension of the sediment was prepared by weighing $2 \mathrm{~g}$ of the sediment into $20 \mathrm{ml}$ of sterile distilled water and agitated gently to avoid forming. The $\mathrm{pH}$ of the suspension was determined using a $\mathrm{pH}$ meter. The concentrations of surfactant were determined using Hyamine titration method (GSD 2002 unpublished). Suspension of the sediment was filtered using Whatmann filter paper $(12.5 \mathrm{~cm})$ and $10 \mathrm{ml}$ of the filterate was measured into a conical flask and $5 \mathrm{ml}$ of dimedium bromide indicator, $15 \mathrm{ml}$ of chloroform, $20 \mathrm{ml}$ of distilled water and 2 drops of phenolphtalein indicator were added to it. The mixture was titrated against $0.004 \mathrm{~N}$ Hyamine solution. The end point was indicated by colour changes from an initial pink to purple then blue. Concentration of surfactant in the sediment was calculated from the titre.

\section{Bacteriological Analysis}

The populations of heterotrophic bacteria in the sediments were enumerated using pour plate method (Eniola and Olayemi 1999). Tenfold serial dilutions of the suspension of the sediment were prepared by pipeting $1 \mathrm{ml}$ of the sediment suspension into $9 \mathrm{ml}$ of sterile diluent. This was repeated to get the $7^{\text {th }}$ dilution and $1 \mathrm{ml}$ each of the sixth and seventh dilutions were measured into separate sterile Petri dish. Cool molten nutrient agar was then poured into the plates, swirled to mix the content properly and then allowed to set. The plates were incubated at $37^{\circ} \mathrm{C}$ for 48 hours. The populations of bacteria that could tolerate $0.1 \%(\mathrm{w} / \mathrm{v})$ of LAS were also enumerated by plating another $1 \mathrm{ml}$ of the seventh dilution on nutrient agar 
into which LAS was incorporated. The isolates were purified, characterized and identified according to Bergey's Manual of Determinative Bacteriology (Buchanan and Gibbons 1974).

The bacteria isolated were tested for tolerance to LAS using media dilution method. Nutrient broth containing varying concentrations $(0.03,0.05,0.07,0.09,0.1 \%)$ of LAS were prepared and inoculated with standardized pure cultures of the isolates. The tubes were incubated at $37^{\circ} \mathrm{C}$ for 48 hours. Un-inoculated tubes of the broth were incubated to serve as control. Data obtained were subjected to statistical analysis using the Analysis of Variance and Pearson product-moment correlation test.

\section{RESULTS}

The sediment samples were found to generally be alkaline in nature; with $\mathrm{pH}$ ranging from $\mathrm{pH} 8.2$ to $\mathrm{pH} 12$. The surfactant concentration were generally high ranging from $45 \mathrm{mg} / \mathrm{g}$ to $132 \mathrm{mg} / \mathrm{g}$. The $\mathrm{pH}$ and concentrations of surfactants in the samples are shown Table 1. The populations of viable heterotrophic bacteria in the samples were generally high. It ranged between $2.9 \times 10^{5}$ and $1.2 \times 10^{7} \mathrm{cfu} / \mathrm{g}$. The population of bacteria that could tolerate $0.1 \%$ of LAS was also generally high. Their population ranged between $1.5 \times 10^{4}$ and $1.2 \times 10^{6} \mathrm{cfu} / \mathrm{g}$. The populations of the viable heterotrophic bacteria and bacteria that could tolerate $0.1 \%$ of LAS are shown on Figure 1. Twelve bacterial isolates were identified; their identity of the organisms and distribution of the bacteria isolated are shown on Table 2. The bacteria showed varying degree of tolerance to LAS; the highest concentration of LAS that each of them could tolerate are shown on Table 3. Statistical analysis showed that a direct relation existed between the $\mathrm{pH}$ and concentration of surfactant $(\mathrm{r}=0.9124)$ and between the populations of heterotrophic bacteria and LTB $(\mathrm{r}=0.9500)$. On the other hand, an inverse relationship existed between populations of heterotrophic bacteria and surfactant concentration $(r=-0.9303)$ and between LTB and surfactant concentration ( $\mathrm{r}$ $=-0.9143$ )

\section{DISCUSSION}

The sediments were consistently alkaline in nature which is attributable to the presence of the surfactant. The surfactant, a sodium salt is alkaline in nature (WHO 1996). Statistical analysis also showed that a direct relationship exited between the concentrations of surfactant in the sediments and their corresponding $\mathrm{pH}$ $(r=0.9144)$. The high concentrations of surfactant are likely to be consequences of discharge of untreated or poorly treated effluents. The concentrations were higher than those reported for rivers in United States (Rapid Creek: 190 $\mathrm{mg} / \mathrm{kg}$, Mississippi River 0.01 to $0.95 \mathrm{mg} /$ $\mathrm{kg}$ ) and Italy (Tiber River: $1.8 \mathrm{mg} / \mathrm{kg}$ ). This is buttressed by the submission of OECD SID (2005) that LAS concentrations in sediment below poorly functioning treatment plants or treatment plants having only primary treatment may be higher.

The high concentration of surfactant in the sediment samples could have also resulted from gradual accumulation, at the bottom, of suspended materials to which the surfactant had

TABLE 1

Physicochemical properties of the sediment samples

\begin{tabular}{lccccccc} 
Parameter & \multicolumn{7}{c}{ Sampling point } \\
& DE & OS1 & OS2 & OK1 & OK2 & RA1 & RA2 \\
pH & 12.0 & 9.2 & 10.0 & 8.8 & 8.9 & 8.3 & 8.2 \\
Surfactant (mg/l) & 132 & 100 & 80 & 60 & 55 & 45 & 40 \\
* Mean values of five replicates. & & & & & &
\end{tabular}




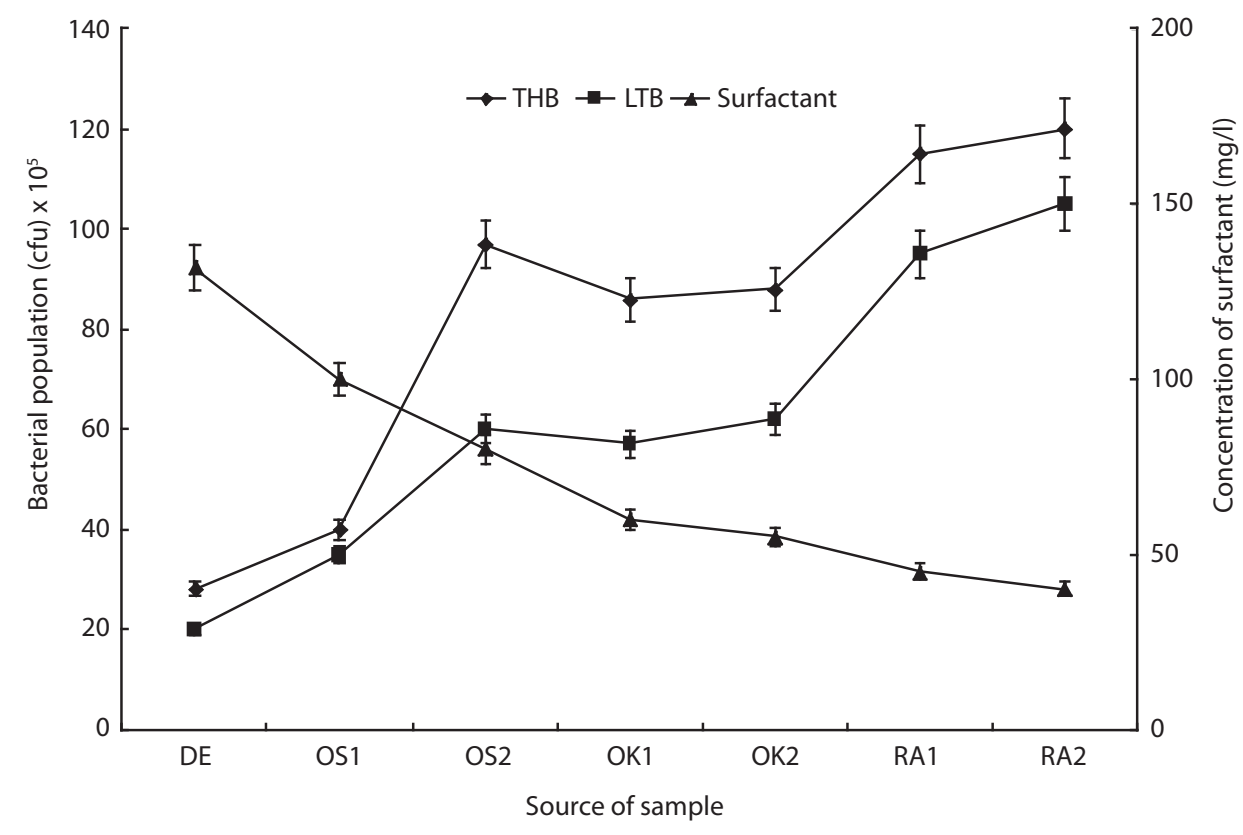

Fig. 1. Population of different categories of bacteria and concentration of surfactant in the sediment samples

TABLE 2

Identity of bacterial isolates and their occurrence in the Streams and River

Organsims

Alcaligenes odorans

Bacillus subtilis

Burkholderia cepacia

Citrobacter freundii

Escherichia coli

Micrococcus albus

Micrococcus luteus

Pseudomonas putida

Pseudomonas stutzeri

Proteus vulgaris

Staphylococcus aureus

Streptococcus bovis 
TABLE 3

Tolerance of LAS by bacteria isolated from the sediments

$\begin{array}{lc}\text { Organsims } & \begin{array}{c}\text { Maximum Tolerated } \\ \text { Concentrations } \\ \text { (MTCs) (mg/l) }\end{array} \\ \text { Alcaligenes odorans } & 1000 \\ \text { Bacillus subtilis } & 1000 \\ \text { Burkholderia cepacia } & 1000 \\ \text { Citrobacter freundii } & 1000 \\ \text { Escherichia coli } & 1000 \\ \text { Micrococcus albus } & 1000 \\ \text { Micrococcus luteus } & 1000 \\ \text { Pseudomonas putida } & 1000 \\ \text { Pseudomonas stutzeri } & 1000 \\ \text { Proteus vulgaris } & 1000 \\ \text { Staphylococcus aureus } & 70 \\ \text { Streptococcus bovis } & 50\end{array}$

adsorbed. This is consistent with the assertion of Cavalli et al. (2000) that suspended solids in the water column form the sediment along the water course. Dentel et al. (1993) estimated that 20 to $50 \%$ of LAS in effluent is adsorbed to solids due to the high adsorption coefficient of the compound. The concentration of LAS in the sediments is however not uniformly spread, Leon et al. (1999) reported that sediment concentration of LAS decreases with depth; but the decrease was not significant in the first few centimeters due to a thin oxic layer. This is attributable to the fact that degradation of LAS proceeds faster in oxic environments and proceeds at very slow rate, if at all, in anoxic conditions. The slow rate of LAS degradation in sediment allows the accumulation of surfactant in the sediment.

The generally high populations of viable heterotrophic bacteria encountered are typical of water bodies that receive organic pollutants. Similar high populations of heterotrophic bacteria have being reported by Olayemi (1994). The populations of bacteria in the sediments were higher than populations reported for the water bodies by Eniola and Olayemi (1999). A study by Olayemi et al. (2003) showed that the sediment of the water bodies haboured a higher population of heterotrophic bacteria than the water column. The high population of bacteria showing ability to grow in the presence of up to $0.1 \%$ of LAS (LAS-tolerant bacteria- LTB) is attributable to the ability of bacteria to be reoriented in response to environmental change and to available nutrient. This is consistent with the submission of some previous workers (Hardman 1989, Takada et al. 1997).

The observed variation in degree of LAStolerance showed by the bacteria is consistent with the report of Folker and Lander (2000). The tolerance pattern is also consistent with reports which showed that Pseudomonas puti$d a$ showed different Ecotoxicity concentration $\left(\mathrm{EC}_{50}\right)$ depending on the exposure (contact) time and concentration. Variations were also reported in the toxicity effect on organisms exposed to LAS in sediment (OECD SID, 2005). Members of Enterobacteriaceae have been observed to show widely varying degree of tolerance to surfactant; but high surfactant tolerance was not uniform to them (Krammer et al. 1980).

Micrococcus luteus and a species of Pseudomonas isolated from the water column were identified as capable utilizing of detergent surfactant (Eniola and Olayemi 2002). $A$. odorans, Micrococcus luteus and Pseudomonas putida have being found to be able to initiate primary degradation of LAS (Eniola, 2005). The ability of these organisms to tolerate high concentrations of LAS makes them important in removal of LAS from water containing high concentration of the surfactant like untreated effluents. The ability of the organisms to withstand high concentration of the surfactant is likely to have resulted from their reorientation/ adaptation due to exposure to the surfactant in effluents as suggested by Takada et al. (1997).

This study clearly demonstrates that the sediment bacteria varied in their response to LAS. This difference in response could be used to monitor levels of surfactant pollution in water. Some of the organisms could also be used in biotreatment of LAS-containing waste water. 


\section{RESUMEN}

La descarga de desechos que contienen detergentes liberan sulfonatos de alquibenceno lineal (LAS) al ambiente acuático. El tensoactivador persiste en algunos arroyos y ríos de Nigeria, en parte es absorbido por materiales en suspensión y termina entre los sedimentos de los cuerpos de agua receptores. En este estudio, bacterias aisladas de los sedimentos de algunos arroyos tropicales que reciben efluentes contaminados con detergentes, fueron analizadas para determinar su tolerancia a los LAS, utilizando la técnica de dilusión del medio. Las bacterias se consideraron tolerantes a los LAS cuando continuaron creciendo aún en presencia del tensoactivador. En los sedimentos también se determinó acidez $(\mathrm{pH})$, concentración de tensoactivador, poblaciones de bacterias heterotróficas y de bacterias tolerantes a los LAS. Se encontró una relación directa $(\mathrm{r}=0.9124)$ entre condiciones alcalinas $(\mathrm{pH}=8.2-12.0)$ y concentraciones altas de tensoactivador (45-132 mg/g) en los sedimentos. Además, los sedimentos mostraron albergar a una población grande y variada de bacterias; las poblaciones de bacterias heterotróficas (VHB: $2.9 \times 10^{5}$ $-1.2 \times 10^{7} \mathrm{cfu} / \mathrm{g}$ ) y bacterias tolerantes a los LAS (LTB: $\left.1.5 \times 10^{4}-1.2 \times 10^{6} \mathrm{cfu} / \mathrm{g}\right)$, mostraron una relación directa $(\mathrm{r}=0.9500)$. Por otra parte, una relación inversa se encontró entre cada una de ellas y la concentración de tensoactivador en los sedimentos, $r_{\mathrm{VHB} / \mathrm{LAS}}=-0.9303 \mathrm{y}_{\mathrm{LTB} / \mathrm{LAS}}=-0.9143$ respectivamente. Doce especies de bacterias fueron aisladas de los sedimentos: Alcaligenes odorans, Bacillus subtilis, Burkholderia cepacia, Citrobacter freundii, Citrobacter diversus, Escherichia coli, Micrococcus luteus, Micrococcus albus, Pseudomonas putida, Pseudomonas stutzeri, Staphylococcus aureus y Streptococcus faecalis. La mayoría de esas especies muestra adaptaciones al tensoactividor, siempre que éste se encuentre en concentraciones entre 0.03 y $1.0 \%(\mathrm{w} / \mathrm{v})$. Los sedimentos pueden servir como una fuente de organismos que pueden ser utilizados en el bio-tratamiento de desechos que contengan LAS.

Palabras clave: LAS, tensoactivador, tolerancia, detergentes, efluentes.

\section{REFERENCES}

Brock, T., D. Madigan, M. T. Martinko, J. M. \& J. Parker 1994. Biology of microorganism (6th editon). Prentice Hall, Englewood Cliffs, Nueva Jersey, USA.

Buchanan, K. E. \& N. E. Gibbons. 1974. Bergey's manual of determinative bacteriology (8th edition). The Williams and Wilkins co. Baltimore, Maryland, USA

Cavalli, L., Cassani, G. Pravettoni, S., Nucci, G. LAzzarin, M. Zatta, A. and L. Vigano (2000). Surfactant in Sediments. CLER Review 6: 100- 111.

De Ferrer, J., A. Moreno, M.T. Vaquero, \& L. Comellas.
1996. The fate of LAS in untreated sewage and high sludge soils. CLER Review. 2: 28-37.

Dentel, S. K., H. E. Allen, C. Srinivasarao, \& J. Divincenzo. 1993. Effects of surfactants on sludge dewatering and pollutant fate. Third year completion report project number 06. Water Resources Center. University of Delaware. Delaware, USA.

Eniola, K.I.T. 2005. Biodegradability studies on detergent surfactant in effluent using resident bacteria of detergent-polluted freshwater bodies in Ilorin, Nigeria. Ph.D Thesis submitted to Department of Microbioogy, University of Ilorin, Kwara, Nigeria.

Eniola, K.I.T. \& A.B. Olayemi. 1999. Impact of effluent from a detergent producing plant on some water bodies in Ilorin. Internat. J. Environ. Health Res. 9: 335-340.

Eniola, K.I.T. \& A.B. Olayemi. 2002. Some aspects of bacterial-detergent interaction in freshwater environments. Biosc. Res. Comm. 14: 645- 649

Folker, J. \& L. Landner. 2000. Risk assessment of LAS in sewage sludge and soil. Report to KemiskTekniska Loverantorbundent (KTF), Stockholm, AFMiljoforskar Gruppen Stockholm- Sweden.

Hardman, D.J. 1989. Microbial control of environmental pollution: The use of genetic techniques to engineer organisms with novel catalytic capabilities. In Environmental Biotechnology. Forster, C.F. and D.A. John Wase (eds). Ellis Horwood, London, England.

Jacques Whitford Limited. 2006. Vancouver Island Transmission Reinforcement Project Technical Data Report: Potential Effects of Alkylbenzene Release to the Marine Environment. Project No. BCV50466.27, Whitford, British Columbia Transmission Corporation, British Columbia, Canada.

Krammer, V. C., D. M. Calabrese \& K.W. Nickerson. 1980. Growth of Enterobacter cloacae in the presence of $25 \%$ sodium dodecyl sulfate. App. Environ. Microbio. 40.5. 973- 976

Larson, R. J., T. M. Rothgeb, R. J. Shimp, T.E. Ward, \& R.M. Ventullo. 1995. Kinetics and practical significance of biodegradation linear alkylbenzene sulfonate (LAS) in the environment. The CLER Review 1: 4- 19.

Leon, V., R. Ponce, E. Gonzalez-Mazo, J.M. Forja, \& Gomez-Parra. 1999. Factor analysis of Linear alkylbenzene sulphonate (LAS) vertical distribution in coastal sediments of Cadiz Bay (southwest Spain). Bol. Inst. Esp Oceanogr.15:509-516.

OECD SIDS. 2005. SIDS Initial Asssesment Report for 20th SIAM. UNEP. Kenya. 
Olayemi, A. B., K.I.T. Eniola, S. Awe \& T.M. Kayoe-isola. 2003. Distribution of Bacteria in three detergenteffluent-polluted water bodies in Ilorin, Nigeria. NISEB Journal. 3.3. 79- 86.

Painter, H.A. \& T.F. Zabel. 1989. The behaviour of LAS in sewage treatment. Tenside surfactant detergents 26 . 108- 115 .

Schulze, S. \& A. Tiehm. 2004. Assessment of microbial natural attenuation in groundwater polluted with gasworks residues. Water Sciences and Technology 50. 5. 347- 353 .

Leon V., R. Ponce, E. Gonzalez-Mazo, J.M. Forja \& A Gomez-Parra. 1999. Factor analysis of Linear alkylbenzene sulphonate (LAS) vertical distribution in coastal sediments of Cadiz Bay (southwest Spain). Bol. Inst. Esp Oceanogr.15:509-516.
Olayemi, A. B. 1994. Bacteriological water assessment of an urban river in Nigeria. Intern. J. Environ. Health Res. 4:156-164.

Takada, H., K. Mutoh, N. Tomita, T. Miyadzu \& N. Ogura. 1997. Rapid removal of LAS by attached biofilm in an urban stream. The CLER Rev. 3:54-65.

WHO. 1996. International Programme on Chemical Safety. Environmental health criteria 169. Linear alkylbenzene sulfonates and related compounds. World Health Organization. Geneva, Swess.

\section{INTERNET REFERENCE}

Council for LAB/LAS Environmental Research (CLER).1996. The Council for LAB/LAS Environmental Research (CLER); www.cler.com (downloaded July 28, 2008). 
